DOI: $10.37279 / 2309-7663-2020-6-3-51-57$

\title{
УДК 314.3
}

В. А. Рубцов,

М. В. Рожко,

Н. М. Биктимиров

\section{Межннациональные браки и их влияние на этнодемографические процессы (на примере Республики Татарстан)}

ФГАОУ ВО «Казанский (Приволжский) федеральный университет», Институт управления, экономики и финансов, г. Казань, Российская Федерация e-mail: niyaz825@mail.ru

Аннотация. В статье рассмотрено влияние межнациональных браков на демографическое развитие населения на примере одного из национальнотерриториальных образований России - Республики Татарстан.

В статье говорится о роли национальности одного из родителей $и$ сохранении различий в межнациональных браках между городским и сельским населением. Раскрыты причины роста межначиональных браков и факторы, влияющие на вступление в такие браки, возможности контактов между этносами, проживающими на территории Татарстана.

Ключевые слова: межнациональные браки, рождаемость, межэтнические контакты, этническая самоидентификачия, разводы, этнос, ассимиляция, Республика Татарстан.

\section{Введение}

Демографическое будущее по своей сути неопределенно, что необходимо учитывать при принятии социально-экономических решений, в том числе маркетинговых, финансовых и других.

Проблема выявления роли этнического фактора в демографическом потенциале в целом, а также его влияния на рождаемость до настоящего времени разработана слабо во многом из-за скудности статистических публикуемых демографических показателей в этническом плане и сложности выявления взаимосвязей данного фактора с другими факторами $[1 ; 2]$.

Как известно, для роста числа межнациональных браков необходимы тесные дружественные межнациональные отношения, относительно высокая миграционная мобильность, особенности расселения населения, ослабление традиций и сглаживание социально-культурного развития, относительное совпадение мировоззрения и т.д. Близость языка и культуры, компенсация диспропорции полового состава также способствуют росту межнациональных браков.

Исследования показывают, что женщины несколько осторожнее относятся к самой возможности таких браков, нежели мужчины.

Давно отмечено, что мужчины и женщины разных национальностей неодинаково по частоте вступают в межнациональные браки. Статистика утверждает, что в межнациональные браки часто вступают люди более взрослые, чем молодые. Прослеживается и следующая взаимосвязь: чем выше уровень образования и культуры человека, тем терпимее он относится к межнациональным бракам. 
Раньше в подобных браках участие русских женщин было существенно выше, чем русских мужчин. Также благодаря многим факторам доля мужчин нерусской национальности в браке с русскими женщинами была выше, чем доля женщин нерусской национальности в браке с русскими мужчинами. Однако в силу ряда особенностей нашей страны дети, родившиеся в этих семьях, в большей степени, регистрировались как русские. Современные социально-культурные преобразования в обществе не формируют преград, а наоборот, только способствуют росту межнациональных браков.

Согласно результатам исследования Н. В. Смольниковой поволжских немцев, более двух третей опрошенных представителей этой национальности состоят в национально-смешанных браках. Среди таких браков абсолютное большинство составляют немецко-русские. Абсолютное большинство информантов, которыми выступали немцы поволжской диаспоры, считают русский народ наиболее близким к своей культуре [3].

Как считает Ислам, для того чтобы в браке были устойчивые и гармоничные отношения молодые люди должны подходить друг другу по религиозности, социальному статусу, уровню образования, и, в том числе, национальности и культуре. Поэтому Ислам считает правильным заключать браки внутри своего собственного народа. Есть и другой аспект, молодые люди, создавая семьи с девушкой другой национальности, повышают вероятность риска того, что девушки из их народа могут остаться вне брака.

В центре семьи и демографии Академии наук Республики Татарстан выяснили: уровень разводимости определенно зависит от моноэтничности или межэтничности семьи. В нашей стране в 1960 г. на 100 свадеб приходилось 12 разводов, в 1985 г. - 41 развод, а в 2005 г. - уже 57. По статистическим данным, в 2009 г. в России на 100 браков приходится 58 разводов.

В настоящее время широкое распространение получили внебрачные связи, растет число семей одиноких матерей, где отсутствует один из важнейших субъектов воспитания - отец [4].

Заключительный отчет по научно-исследовательской работе коллектива ученых из Казанского федерального университета под руководством Е. П. Бусыгина «Этнические культурно-бытовые процессы в Среднем Поволжье» позволяет уточнить вопросы, в первую очередь относящиеся к основным этносам республики - русским и татарам. Так, результаты отчета показали, что развитие политической суверенизации, оказало и продолжает по сей день оказывать влияние на этнические процессы в регионе. Важным указывается то, что этническое самосознание большинства разнонациональных супругов четкое, значимо при определении собственной этнической принадлежности. Для большинства жителей Татарстана (русских и татар) присущи четкие автостереотипы, учет этноконсолидирующих и этнодифференцирующих признаков. При этнической самоидентификации детей в условиях Республики Татарстан решающую роль играет этническая принадлежность отца и доминирующий на уровне непосредственного окружения язык [5].

Как известно, международные миграции способствуют изменению национальности в тех или иных государствах. Часто это преследуется для облегчения получения подданства новой страны. Это явление особенно характерно для стран с депрессивным состоянием экономики. Возможно также, что межнациональные браки будут способствовать появлению космополитов. 
Решение о миграции люди принимают на основании своих предпочтений в выборе места работы и жизни, основываясь, не только на социальноэкономических условиях, но и психоэмоциональных переживаниях еще на этапе подготовки к миграции. Существует определенная сложность в получении данных о мигрантах до того момента, когда они перемещаются [6].

Для многих регионов мира верно то, что экономический рост стимулирует миграцию населения, ее последствия заметны и разнообразны как для развитых, так и развивающихся стран и проявляются как в сугубо экономической сфере, например, на рынке труда, так и в социальной - ассимиляция мигрантов, межэтническое взаимодействие, изменение рождаемости. И тем и другим последствиям посвящено немалое количество публикаций по миграционной проблематике [7].

\section{Материалы и методы}

Неопределенность демографического будущего создается, главным образом, в связи со сложностью понимания демографических процессов, несовершенством демографических данных, непредсказуемостью миграционной политики и рядом других явлений. Для ее преодоления демографами предлагаются различные модели, прежде всего, основанные на данных о рождаемости, смертности и миграции [8].

Демографический анализ следует рассматривать как неотъемлемый центральный элемент изучения воспроизводства населения, расселения, связанный с разработкой принципов применения статистических, математических, социологических, картографических и других методов.

При написании статьи были использованы методы системно-структурного анализа, сравнительно-аналитический метод.

Подробное изучение межнациональных браков требует использования огромного статистического материала. Обзор литературы по данной теме и статистических данных, подтвердил, что материалов, раскрывающих межнациональные браки, недостаточно.

\section{Результаты и обсуждение}

Межнациональные браки начали играть существенную роль в демографическом развитии населения Республики Татарстан. Об этом позволяют судить имеющиеся данные. Так, если в 1990 г. доля родившихся от родителей разных национальностей составила в целом по республике $20,7 \%$ от всех родившихся, в 1998 г. - 26,4\%, в 2002 г. - 33,5\%. В период с 2010 года по настоящее время более чем одна треть всех детей рождается в смешанных браках. Анализ данных по населению Республики Татарстан по данным переписи 2002 и 2010 г. позволяет отметить, что основными участниками в этих процессах являются русские и татары.

Если в более ранних этапах в смешанных браках доля татар была незначительной, то уже в 2002 г. у $25,9 \%$ родившихся отцы были носителями нетатарской национальности. Среди городского населения доля родившихся в смешанных браках, считающихся татарами, значительно больше $(32,5 \%)$, чем среди сельского $(13,4 \%)$. Интересно то, что у женщин-татарок, проживающих в 
городах за пределами республики, доля участия в межэтнических контактах выше.

Можно говорить, что наблюдаемая высокая рождаемость от смешанных браков, в какой-то мере компенсирует в первую очередь, низкую рождаемость у русских. Так, в наибольшей степени отмечен рост (на 17,2 процентных пункта за 13 лет) доли детей, отцы которых имели другую национальность. Данная тенденция характерна как для городского, так и для сельского населения.

Возможности контактов между этносами, проживающими на территории Татарстана, велика у пар татары-русские и достаточно выражены у пар татарымарийцы, татары-удмурты, русские-мордва, чуваши-мордва, марийцыудмурты. В последние годы в рост пошли браки с армянами и азербайджанцами, а также с другими народами Кавказа.

Как правило, смешанные браки отличаются высокой рождаемостью. Мужчины имеют жен, соответствующих или близких по уровню квалификации, а женщины в большинстве случаев имеют семьи, созданные с мужчинами с более низкой квалификацией.

В размещении национально-смешанных семей, в Республике Татарстан прослеживаются следующие тенденции:

1) неравномерность размещения;

2) стягивание к крупным, многофункциональным, наиболее этнически смешанным населенным пунктам;

3) положение вблизи крупных городов и магистральных дорог.

Основными проблемами, возникшими в результате межнациональных браков, следует назвать определение национальности детей; конфликты в большинстве случаев между детьми и родителями по национально-этническим вопросам; опасения утраты языка, обычаев, традиций между вступающими в брак и их потомками. Важной особенностью лиц, состоящих в смешанных браках, является отрицательная реакция на все, что связано с интерпретацией национальности, отношения к межнациональным бракам и т.п.

Многие считают, что в смешанных браках рождаются более здоровые, крупные, более способные и талантливые дети. Отчасти это так. Если речь идет об очень различных по происхождению супругах, то, действительно, их дети могут быть более крупные и более жизнеспособные. Однако этот эффект не наследуется, он проявляется только в первом поколении и в дальнейшем затухает. К тому же в таких браках с генетически очень разошедшимися линиями может возникнуть внутриутробный конфликт ребенка с матерью за счет присутствия в генотипе ребенка отцовских генов.

Следует учитывать тот факт, что дети, рожденные и воспитанные в национально-смешанных семьях, часто в последующем для создания семьи выбирают партнеров-потомков от другого национально-смешанного брака. Тем самым усложняются наследственные связи и география расселения основных национальностей.

Городское и сельское население всегда отличалось по доле лиц, состоящих в смешанном браке. Большое число смешанных браков в городах, в отличие от сельских местностей, можно объяснить следующим: городское население более мобильно, и город создает условия для развития личных контактов у лиц разных национальностей в различных сферах общества. 
Доля татарско-русских браков в сельской местности составляет 63\% от всех национально-смешанных браков.

Характер межнациональных браков на разных территориях может существенно различаться. В какой-то мере это можно показать на примере сохранения татарской и башкирской нации, исторически проживающих на смежных территориях. Здесь факты вступления в межнациональные браки встречались крайне редко, особенно в сельской местности. Например, количество мужчин соответствующей национальности, вступивших в брак с русскими женщинами в 1926 г., составляло лишь 1\%. Рост межэтнических браков способствует естественному протеканию ассимиляционных этнических процессов.

Несмотря на сказанное, во многих многонациональных странах возможность выбора этнической общности отца и матери в большинстве случаев заканчивается выбором национальности отца. Выбор же национальности матери в большинстве случаев обусловлен её более высоким социально-культурным статусом и нахождением семьи на территории коренной этнической среды матери. Как в русско-татарских, так и татарско-русских семьях, важную роль в этнической самоидентификации детей играет национальность отца, кроме того, в татарскорусских семьях - доминирующий язык. Внутри этнической группы основной переводчик этнокультурной информации - мать.

\section{Выводы}

Благодаря изучению межнациональных браков, возможно, со временем будет сформирован определенный свод правил, относящихся к определению национальности новорожденного, что намного облегчит разрешение данной проблемы в смешанных семьях. Так, не исключено принятие такого варианта, когда новорожденный будет иметь национальность жителей населенного пункта, где прослеживается четкое преобладание представителей какой-то национальности, а при отсутствии преобладания конкретного народа, возможно, разумнее иметь национальность отца и т.д.

\section{Лumepamypa}

1. Biktimirov, N., Gaisin, R., Gaisin, I. The use of new methodologies for demographic investigations in national-territorial subdivisions of Russia // Life Sci J. 2014. Vol. 11, № 8, Pp. 194-197.

2. Gaisin, R., Gaisin, I., Biktimirov, N. The use of new methodologies for demograpfic investigation in national territorial subdivisions of Russia // Life Sci J. 2014. vol. 11 (8s), Pp. 198-2003.

3. Смольникова Н.В. Современная этнополитическая ситуация и межэтнические отношения в Нижнем Поволжье (на примере немецкой диаспоры) Автореф. дис. канд. ист. наук. Москва, 1998. [Электронный ресурс]. Режим доступа: http://cheloveknauka.com/sovremennaya-etnopoliticheskaya-situatsiya-imezhetnicheskie-otnosheniya-v-nizhnem-povolzhie (дата обращения 25.02.2020)

4. Rubtzov, V. A., Gabdrakhmanov, N. K., Delabarr, O. A. \& Tyabina, D. V. "Equilibrium tasks in geography", Mediterranean Journal of Social Sciences. 2015. vol. 6, no. 3, Pp. 669-672. 
5. Бусыгин Е. П. Отчет о научно-исследовательской работе. Этнокультурнообщественные процессы на Среднем Поволжье / Наука. Темы Казань. Издательство КГУ, 1996. 16 с.

6. Yija la, A., Jasinskaja-Lahti, I. Pre-migration acculturation attitudes among potential ethnic migrants from Russia to Finland // International Journal of Intercultural Relations. 2010. vol. 34, Pp. 326-339.

7. Prayitno, G., Matsushima, K., Jeong, H., Kobayashi, K. Social Capital and Migration in Rural Area Development // Procedia Environmental Sciences. 2014. vol. 20, Pp. 543-552.

8. Hyndman, R., Booth, H. Stochastic population forecasts using functional data models for mortality, fertility and migration // International Journal of Forecasting. 2008. Vol.6, №24, Pp. 323-342.

\section{A. Rubtzov, M. V. Rozhko, N. M. Biktimirov}

\section{Interethnic marriages and their influence on ethno-demographic processes (on the example of the Republic of Tatarstan)}

Kazan Federal University, Institute of Management, Economics and Finance, Kazan, Russian Federation

e-mail: niyaz825@mail.ru

Abstract. The article considers the influence of interethnic marriages on the demographic development of the population on the example of one of the nationalterritorial entities of Russia - the Republic of Tatarstan.

The article talks about the role of the nationality of one of the parents and the preservation of differences in interethnic marriages between urban and rural populations. The reasons for the growth of interethnic marriages and factors affecting the entry into such marriages, the possibilities of contacts between ethnic groups living in the territory of Tatarstan are revealed.

Keywords: interethnic marriages, birth rates, interethnic contacts, ethnic selfidentification, divorces, ethnicity, assimilation, Republic of Tatarstan.

\section{References}

1. Biktimirov, N., Gaisin, R., Gaisin, I. The use of new methodologies for demographic investigations in national-territorial subdivisions of Russia // Life Sci J . 2014. Vol. 11, № 8, Pp. 194-197.

2. Gaisin, R., Gaisin, I., Biktimirov, N. The use of new methodologies for demograpfic investigation in national territorial subdivisions of Russia // Life Sci J. 2014. vol. 11 (8s), Pp. 198-2003.

3. Smol`nikova N. V. Sovremennaya e`tnopoliticheskaya situaciya i mezhe` tnicheskie otnosheniya v Nizhnem Povolzh`e (na primere nemeczkoj diaspory`) Avtoref. dis. kand. ist.nauk. Moskva, 1998. URL: http://cheloveknauka.com/sovremennayaetnopoliticheskaya-situatsiya-i-mezhetnicheskie-otnosheniya-v-nizhnem-povolzhie (in Russian)

4. Rubtzov, V. A., Gabdrakhmanov, N. K., Delabarr, O. A. \& Tyabina, D. V. "Equilibrium tasks in geography", Mediterranean Journal of Social Sciences. 2015. vol. 6, no. 3, Pp. 669-672. 
5. Busy`gin E. P. Otchet o nauchno-issledovatel`skoj rabote. E`tnokul'turnoobshhestvenny`e processy` na Srednem Povolzh`e / Busy`gin. Kazan`. Izdatel`stvo KGU, 1996. 16 s. (in Russian)

6. Yija"la“, A., Jasinskaja-Lahti, I. Pre-migration acculturation attitudes among potential ethnic migrants from Russia to Finland // International Journal of Intercultural Relations. 2010. vol. 34, Pp. 326-339.

7. Prayitno, G., Matsushima, K., Jeong, H., Kobayashi, K. Social Capital and Migration in Rural Area Development // Procedia Environmental Sciences. 2014. vol. 20, Pp. 543-552.

8. Hyndman, R., Booth, H. Stochastic population forecasts using functional data models for mortality, fertility and migration // International Journal of Forecasting. 2008. Vol.6, № 24, Pp. 323-342.

Поступила в редакциюю 25.06.2020 2. 